\title{
Ser ou não ser, eis a questão: a crítica aprisionada na caverna de Platão
}

\section{To be or not to be, that is the question: the critique trapped in the cave of Plato}

Ana Paula Paes de Paula ${ }^{1}$

O que é a crítica afinal? Não é a primeira vez que fazemos essa pergunta, e a questão foi tratada anteriormente no livro Teoria crítica nas organizações (PAES DE PAULA, 2008). ${ }^{2}$ No entanto, os textos que fazem parte deste fórum e a atual conjuntura dos estudos críticos organizacionais no Brasil trazem novamente a questão à tona.

Debatendo com nossos pares, muitas vezes, fomos questionados sobre a relevância de se responder a essa pergunta e se isso realmente poderia contribuir para a evolução do conhecimento na área. Ora, o fato é que a questão continua se impondo e isso nos leva a refletir sobre o seu significado. Disputa de espaço acadêmico, divergências ideológicas, diferenças epistemológicas, interesses políticos: essas são algumas hipóteses que gostaríamos de deixar em suspenso, pois talvez nenhuma delas explique o fenômeno.

Se for a clareza sobre o que seja a crítica que hoje nos mobiliza, acreditamos que vale a pena nos debruçarmos novamente sobre a questão. No entanto, dessa vez, vamos tentar uma nova abordagem, retornando às origens, para tentar esclarecer o que é a crítica e porque isso é hoje objeto de nossas preocupações. Antes de tudo, é impossível entender o que seja a crítica sem resgatar algumas questões fundamentais que animaram a história da filosofia. Retornando no tempo, temos, de um lado, Platão, para quem o mundo concreto percebido pelos nossos sentidos é uma reprodução do mundo das ideias, e de outro, Aristóteles, que discordando de seu mestre defende que nada existe além do que se apresenta aos nossos sentidos. É possível apontar no platonismo e na

\footnotetext{
* Gostaria de agradecer a Amon Narciso de Barros e a Carolina Machado Saraiva de Albuquerque Maranhão pela leitura atenta, os comentários e as sugestões feitas para a melhoria do texto.

'Pós-Doutora em Administração pela Escola de Administração do Empresas de São Paulo da Fundação Getulio Vargas (EAESP/FGV) e Doutora em Ciências Sociais pelo Instituto de Filosofia e Ciências Humanas da -Universidade Estadual de Campinas (IFCH/UNICAMP). Professora adjunta do Centro de Pós-Graduação e Pesquisas em Administração da Universidade Federal de Minas Gerais. Endereço: Av. Antônio Carlos, 6.627 - Campus Pampulha - Faculdade de Ciências Econômicas CEPEAD Belo Horizonte - Minas Gerais - Brasil - CEP: 31270-901. E-mail: appaula@face.ufmg.br

${ }^{2}$ Cabe talvez um esclarecimento público: o título do livro foi uma decisão editorial. Preferiamos "Estudos críticos e organizações" ou "Teoria crítica e organizações".
} 
sua teoria das ideias as raízes do idealismo e da filosofia metafísica; no pensamento aristotélico, o germe do materialismo e da filosofia positivista, da qual se originou a ciência moderna.

Platão nos inicia no dilema da condição humana com o mito da caverna: o homem que consegue abandonar as sombras (domínio das coisas sensíveis) e ter com a luz que vem de fora da caverna (domínio das ideias) teria realizado a passagem do senso comum como visão de mundo para a explicação da realidade a partir do conhecimento filosófico, superando sua condição de ignorância. Aristóteles, por sua vez, estabelece as bases do conhecimento fundamentado na experiência - ou seja, do conhecimento científico e da atividade artística -, delineando seus tratados de lógica, física, doutrina da alma (origem da estética e, mais tarde, da psicologia), ética e política.

Constituiu-se assim o coração da filosofia e também suas paixões. A partir de então, a história da filosofia seria permeada por pensadores que defendem a metafísica ${ }^{3}$ ou o positivismo. Na perspectiva da metafísica, a filosofia é o único saber possível, de modo que precede a ciência, que não seria um saber, mas um conjunto de expedientes práticos para codificar a realidade. Para o positivismo, o conhecimento cabe às ciências e a tarefa da filosofia seria coordenar e unificar seus resultados. Em outras palavras, se estabeleceu o "cabo de força" que opõe o idealismo ao materialismo: filosofia e ciência se debatendo para estabelecer a verdade. Para equilibrar estas forças, surgiu um árbitro, a crítica, para a qual cabe à filosofia realizar o juízo sobre a ciência e sobre a própria filosofia, interrogando suas verdades e buscando estabelecer a validade do conhecimento e o seu potencial.

A arbitragem se fez necessária para que o homem, ao abandonar as sombras do domínio das coisas sensíveis, pudesse ter com a realidade sem apreender o real meramente como fruto de sua percepção, sem ser logrado pelas verdades estabelecidas a partir do exame do mundo material e sem se deixar enganar pelas verdades estabelecidas pelo domínio das ideias, o que o submerge nas ideologias. Isto é, o homem deveria ter condições de julgar o conhecimento científico (baseado na realidade material) e o conhecimento filosófico (baseado no mundo das ideias) e chegar à verdade. Somente dessa forma, ao abandonar sombras da caverna para ter com a luz, realmente, teria superado a ignorância; em outras palavras, poderia ser considerado um ser emancipado. Portanto, a crítica nasceu para nos proteger do conhecimento que é capaz de gerar nossa ignorância, sendo movida pela possibilidade de sairmos da sombra opressora da ingenuidade e encontrar a luz da razão. Alguns pensadores acreditam que o papel da filosofia não é competir com a ciência pelo estabelecimento da verdade, mas, justamente, interrogar as verdades estabelecidas. Nessa perspectiva, a filosofia se confunde com a própria crítica.

As bases da crítica são a verdade e a dúvida, elementos indispensáveis da condição humana, visto que permeada pela racionalidade. A crítica assim se beneficiou, ainda no período helenístico, do ceticismo filosófico, que significa "olhar à distância", "examinar", "observar", porque não há certeza a respeito da verdade e o filósofo precisa analisar de forma crítica o conhecimento e a percepção para ver se estes são verdadeiros. O ceticismo, no entanto, gerou um dos grandes paradoxos da crítica: no limite, a dúvida nunca acaba, de modo que nenhuma verdade ou conhecimento é possível, pois o juízo fica eternamente retido. $\mathrm{O}$ idealismo não é mais admitido e o homem estaria, assim, ironicamente, condenado a ficar submerso nas trevas devido a sua busca incessante da verdade e do conhecimento. Então, a questão seria saber até onde o crítico pode ir com o seu questionamento, para não se tornar um cético.

Emerge assim outro paradoxo da crítica: ela não é um árbitro totalmente neutro, pois na sua tentativa de mediar o "cabo de forças" puxado pelo materialismo e pelo idealismo, seu coração bate mais forte pelo idealismo. Ora, a filosofia é a filha das ideias: como poderia ela fazer a crítica da verdade e do conhecimento estabelecidos somente observando o mundo material, sem recorrer ao mundo das ideias? Se seu fundamento para fazer a crítica fosse o mundo material, ela não seria filosofia, mas ciência - que, aliás, é filha da filosofia-, e também não poderia existir sem o mundo das ideias. É certo que o mundo material existia antes de nós, mas o fato é que ele não adquiriu significado apenas com a nossa presença, mas sim com o nosso pensamento.

\footnotetext{
${ }^{3}$ Estamos utilizando a palavra metafísica como sinônimo de filosofia: a filosofia primeira, na concepção aristotélica (Dicionário Houaiss).
} 
A origem da crítica coloca-nos, de saída, dois pontos fundamentais para a nossa discussão. Em primeiro lugar, a crítica antecede todo o pensamento moderno; ou seja, precedeu o idealismo alemão, o marxismo, a fenomenologia, o existencialismo, a teoria crítica e o pós-estruturalismo. Em segundo lugar, a crítica se fez cada vez mais necessária na era moderna, uma vez que a ciência ganhou lugar de destaque e a filosofia teve que se repensar inúmeras vezes para compreender os fenômenos e conhecimentos gerados pelos novos tempos, preservando a racionalidade humana.

Em alguns artigos apresentados neste fórum os autores procuram apontar que a fenomenologia e o existencialismo não são críticos, que a teoria crítica teria superado o idealismo, como afirmou Faria neste número temático, e que o pós-estruturalismo é crítico como sugerem, também neste número, Alcadipani e Tureta. Neste comentário, vamos tentar demonstrar que pelo fato de o idealismo alemão, a fenomenologia, o existencialismo e o pós-estruturalismo não serem correntes positivistas, tendemos a categorizá-las como metafísicas, uma vez que não defendem a ciência, mas a filosofia. No entanto, não é possível dizer que elas sejam exclusivamente metafísicas, pois se baseiam em formas de pensar que buscam a verdade, de modo que podem ser caracterizadas como críticas. Desse modo, é mais seguro afirmar que uma determinada tradição filosófica pode realizar, à sua maneira, crítica, do que dizer que ela não realiza crítica alguma. Em outras palavras, tentar isolar uma única forma de crítica contraria a própria razão de ser da filosofia. Metaforicamente, podemos dizer que aprisiona a crítica na caverna de Platão, pois a preocupação passa a ser a busca incessante do que é a crítica e, assim, impedimos que ela alcance seu propósito, que é o esclarecimento humano.

Para desenvolver essas ideias, vamos abordar em primeiro lugar a teoria crítica, que é a corrente filosofica que se propõe a resgatar a crítica na filosofia, demonstrando como ela interroga o marxismo como ciência. Além disso, procuraremos evidenciar que a filosofia, na busca da verdade, gera novas formas de pensar, como a dialética marxista, a dialética negativa e o jogo pós-estruturalista da diferença, as quais, sem exceção, podem ser consideradas modalidades de crítica. Em seguida, examinaremos a fenomenologia e o existencialismo como formas de filosofar em uma perspectiva crítica, evidenciando que estas, assim como a teoria crítica, sofreram forte influência do idealismo alemão e do humanismo, e que, apesar dos pontos em comum e de serem contemporâneas, apresentaram-se na sua época como se estivessem em campos distintos. Tal fato será então relacionado com o tempo presente, a fim de demonstrarmos por que Guerreiro Ramos pode ser considerado um crítico e demarcarmos a importância de deixar a crítica se libertar da carverna de Platão.

\section{O marxismo interrogado pela Escola de Frankfurt}

A leitura atenta da teoria crítica de primeira geração revela claramente a herança marxista, particularmente calcada na fase filosófica da obra de Marx, embora também tenha sido profundamente influenciada pela psicanálise, que permeia o pensamento de seus principais representantes: Horkheimer, Adorno e Marcuse. Em outras palavras, o marxismo que se apresenta na Escola de Frankfurt está fundamentado na centralidade do sujeito, manifestando-se de forma bastante heterodoxa, na medida em que é profundamente crítico à fase madura da obra de Marx - considerada científica por alguns -, na qual este desenvolve sua análise da economia política. Na verdade, considerando que a teoria crítica é uma escola filosófica essencialmente antipositivista e não uma escola científica, não surpreende que o marxismo, como ciência, tenha sido profundamente questionado.

Assim, ainda que haja heterogeneidade de posicionamentos entre seus diversos autores, quando examinamos o pensamento de seus principais representantes, notabiliza-se a maneira como estes interrogam o marxismo, colocando em questão a forma como foi utilizado o materialismo histórico e dialético e argumentando sobre a força de outras categorias, às quais Marx não tinha condições de dar a devida importância, uma vez que viveu em outro tempo histórico. Os frankfurtianos vão demonstrar, por exemplo, que a opressão na esfera de circulação das mercadorias - na qual situamos as relações de distribuição e de consumo - estaria indo além da verificada na esfera de produção - na qual situamos as relações de produção -, na medida em que a evolução das forças produtivas estaria diluindo os conflitos entre capital e trabalho no chão de fábrica e em que a alienação gerada pelo trabalho se somou à crescente alienação promovida pela indústria cultural. Desse modo, a centralidade da categoria trabalho passou a ser dividida com a categoria cultura. 
Em seu ensaio "Marx superado?" Adorno (1974) realiza uma competente análise da teoria marxista, demonstrando como a lógica do materialismo histórico e do materialismo dialético teriam levado marxistas a se equivocarem afirmando que a evolução das forças produtivas - ou seja, o progresso técnico - modificaria as relações de produção. Por outro lado, a profecia de que o proletariado seria a classe protagonista da revolução caiu por terra, na medida em que esta mesma classe, por meio do trabalho e da possibilidade de participar da sociedade de consumo, tornou-se cada vez mais integrada à sociedade burguesa. Essa conclusão foi magistralmente demonstrada por Adorno e Horkheimer (1985) em Dialética do Esclarecimento..., quando, utilizando o mito homérico de Ulisses, os autores demonstraram que os remadores do barco (classe proletária), na verdade, desejavam se transformar no seu capitão Ulisses (classe média), que amarrado ao mastro do navio podia ouvir o canto das sereias (a autorrealização sacrificada) sem sucumbir a elas (autoconservação do seu papel social fruindo dos produtos alienantes da indústria cultural).

Adorno (1974) também revela que o capitalismo estaria desenvolvendo suas formas de exploração não apenas no campo da produção material de mercadorias, mas na esfera da distribuição, da administração e da cultura. As forças produtivas não estariam em contradição com as relações de produção, como concluíram alguns marxistas, mas em perfeita consonância com as mesmas. Assim, as relações de produção não teriam mais como fundamento de opressão a propriedade, mas a própria administração realizada por meio delas. Em outros termos, a superação da forma privada de propriedade não é condição suficiente para superar a opressão, fato que tem sido amplamente comprovado, por exemplo, pelas cooperativas que coletivizam seus meios de produção. Ora, essa superação precisa se dar no campo da superestrutura, ou seja, da ideologia, da visão de mundo e da forma como os trabalhadores lidam com o seu imaginário e ideias.

Dessa forma, ainda que a opressão tenha se aprofundado com o capitalismo, o fato é que ela sempre existiu e não depende exclusivamente da mudança nas condições materiais, mas também da transformação nas condições ideológicas. Horkheimer é muito claro a esse respeito no comentário "Filosofia e teoria crítica" (HORKHEIMER, 1980b), que escreve sobre seu próprio texto "Teoria crítica e teoria tradicional" (HORKHEIMER, 1980a). Sua intenção primeira é a critica de qualquer forma de teoria que se fundamente no positivismo (teoria tradicional), mas, de forma subjacente, procura demonstrar a importância do idealismo para teoria crítica. Para isso, declara abertamente o alinhamento da teoria crítica com o idealismo alemão:

A teoria crítica da sociedade está de acordo com o idealismo alemão no que diz respeito à relação da produção humana com o material dos fatos aparentemente últimos, aos quais o especialista tem que se ater. Desde Kant, o idealismo tem contraposto este momento dinâmico de veneração dos fatos ao conformismo social subsequente. [...] Este pensamento que considera como espiritual a atividade materialmente dada, situando-se na consciência supraempírica em si, no Eu absoluto, no Espírito, é geral no idealismo alemão. A superação deste seu aspecto apático, inconsciente e irracional fica, por princípio, a cargo do interior da pessoa, isto é, da convicção moral. Para a concepção materialista, ao contrário, esta atividade fundamental consiste no trabalho social, cujo caráter de classe imprime sua forma em todos os modos de reagir humanos, inclusive, na teoria. A penetração racional do processo no qual a gnose e seu objeto se constituem, sua subordinação ao controle da consciência, não transcorre por isso num terreno exclusivamente espiritual, mas coincide com a luta por determinadas formas de vida na realidade efetiva. [...] A teoria crítica, ao contrário, na formação de suas categorias e em todas de seu desenvolvimento, segue conscientemente o interesse por uma organização racional da atividade humana: clarificar e legitimar esse interesse é a tarefa que ela confere a si própria. Pois para a teoria crítica, não se trata apenas dos fins, tais como são apresentados pelas formas de vida vigentes, mas dos homens com todas suas possibilidades. É nesse sentido que a teoria crítica preserva a herança não só do idealismo alemão, mas da própria filosofia. Ela não é uma hipótese de trabalho qualquer que se mostra útil para o funcionamento do sistema dominante, mas sim um momento inseparável do esforço histórico de criar um mundo que satisfaça às necessidades e forças humanas. (HORKHEIMER, 1980b, p.156) 
Pedimos desculpas pela longa citação, mas ela é importante, uma vez que deixa clara a opinião de Horkheimer sobre a vinculação da teoria crítica ao idealismo e deste à própria razão de ser da filosofia. Há, sim, o "cabo de força" entre idealismo e materialismo, que a crítica procura arbitrar, mas sua vinculação com a filosofia leva a crítica a admitir que um mundo transformado não seja possível sem passarmos pelo domínio das ideias. O fato é que ainda que Adorno e o próprio Marx tenham questionado o idealismo, nunca conseguiram se desprender dele e nem da filosofia da consciência, pois ainda que a realidade material se imponha, não há crítica possível sem o mundo das ideias e a presença do sujeito. Tanto Habermas (1990) quanto Nobre (1998) alertaram para a dificuldade que Adorno enfrentou para superar esse dilema.

Horkheimer (1980b) ainda demonstra que os conceitos com os quais a teoria crítica lida são aqueles que importam para o presente, de modo que se hoje falamos de classe, exploração, mais-valia, lucro e pauperização, isso ocorre porque o capitalismo é o modo explicativo da opressão contemporânea. Os conceitos poderiam ser outros, se outra fosse a realidade, pois o que importa, de fato, não é buscar sentido na reprodução da sociedade atual, mas, sim, refletir sobre a possibilidade de sua transformação. Do mesmo modo, Horkheimer se preocupa em evidenciar que a crítica não nasceu com o marxismo:

[...] a teoria crítica não almeja de forma alguma apenas uma ampliação do saber, ela intenciona emancipar o homem de uma situação escravizadora. Nesse sentido ela corresponde à filosofia grega, não tanto à do período de resignação quanto à do auge com Platão e Aristóteles. Enquanto estoicos e epicuristas voltam a doutrinas de práticas individualistas, após o fracasso dos projetos políticos daqueles dois grandes filósofos, a nova filosofia dialética, ao contrário, parte do conhecimento de que o desenvolvimento livre dos indivíduos depende da constituição racional da sociedade. Ao focalizar as bases da situação atual, ela passa a ser a crítica da economia. A crítica, todavia, não é idêntica ao seu objeto. A economia política não é uma espécie de cristalização do pensamento filosófico. (HORKHEIMER, 1980b, p.156-157)

Nessa citação, Horkheimer situa a origem da crítica na filosofia grega e questiona os filósofos helenistas estoicos e epicuristas que partilharam seu tempo com os céticos. Ele chama a atenção para o fato da dialética ser uma nova tentativa de salvar a filosofia de sua imersão no positivismo, e que por isso não deveria, no seu ponto de vista, sucumbir à economia política, visto que esta é uma ciência. Por esse motivo, continua afirmando:

[...] a teoria crítica da sociedade, mesmo enquanto crítica da economia, permanece filosófica. [...] $O$ Capital em suas análises não é menos exato que a economia política criticada, mas mesmo nos cálculos mais sutis de processos isolados, que se repetem periodicamente, o conhecimento do desenrolar histórico da totalidade continua sendo o motivo propulsor. Não é um objeto filosófico particular, mas é a consideração das tendências da sociedade global que é decisiva, mesmo nas suas ponderações mais abstratas, lógicas e econômicas. (HORKHEIMER, 1980b, p.157)

Essa afirmação corrobora o caráter heterodoxo do marxismo dos frankfurtianos sobre o qual argumentamos anteriormente, bem como a apreciação que os mesmos fazem da obra filosófica de Marx em contraposição à obra de maturidade, considerada científica por alguns. Horkheimer completa seu raciocínio, demonstrando também que a transformação nas condições materiais não representa libertação da situação de opressão se não houver mudança nas condições ideológicas:

O próximo objetivo histórico é, de fato, a abolição das relações sociais que emperram atualmente o desenvolvimento social. Abolição, no entanto, é um conceito dialético. A transformação dos bens privados em propriedade estatal, a expansão industrial e mesmo o amplo contentamento das massas terão o seu significado histórico definido apenas na natureza do todo, no qual estão inseridos. [...] A crítica teórica e prática tem que focalizar primeiramente a causa primeira da miséria, a economia. Mas julgar também as formas de sociedade futura, baseando-se apenas na economia, não seria um pensamento dialético, mas sim mecanicista. A transformação histórica não deixa intocáveis as esferas culturais. E se no estado atual da sociedade a economia domina os homens e constitui, por isso, a 
alavanca com a qual esse estado deve ser transformado face às necessidades naturais, no futuro os homens mesmos devem determinar os seus relacionamentos. (HORKHEIMER, 1980b, p.158-159)

Em Ideologia da sociedade industrial Marcuse (1979) retoma as elaborações de Adorno e Horkheimer (1985), comprovando o caráter opressor da sociedade fundamentada no consumo, concluindo também que uma teoria crítica da sociedade implica dois questionamentos: se a vida humana vale a pena ser vivida e se, em determinada sociedade, existem possibilidades específicas de melhorar a vida humana e modos e meios específicos de concretizar tais possibilidades. No seu ponto de vista, responder a essas perguntas implica um julgamento de valores, cabendo à análise crítica demonstrar a validez objetiva dos mesmos, baseando-se na realidade empírica que, por sua vez, está fundamentada na escassez de recursos e na sua distribuição. No entanto, para identificar e definir as melhores possibilidades de desenvolvimento:

[...] a teoria crítica deve se abstrair da organização e utilização práticas dos recursos na sociedade, bem como dos resultados dessa organização e utilização. Tal abstração, que se nega a aceitar o universo dos fatos dado como o contexto final da validação, tal análise "transcendente" aos fatos à luz de suas possibilidades, captadas e negadas, pertence à própria estrutura da teoria social. (MARCUSE, 1979, p.15)

Da mesma forma que Horkheimer, Marcuse questiona a noção de que as mudanças nas condições materiais sejam suficientes para transformar a sociedade. Mais do que isso, ele afirma que a teoria crítica só se concretiza quando consegue abstrair-se de um real que aponta para a impossibilidade de mudança, visando alcançar uma transcendência, possível no mundo das ideias, que demonstre qual é o caminho para essa mudança. Em outras palavras, Marcuse também releva a dependência da crítica em relação ao idealismo.

Em Dialéctica negativa, Adorno (1975) nos alertou para os riscos desse idealismo, demonstrando que a tese marxista de que a evolução das forças produtivas levaria à modificação das relações de produção teria se transformado em uma "ilusão socialmente necessária", que a teoria crítica deveria rechaçar. De acordo com Nobre (1998), a intenção de Adorno não teria sido reformular o quadro teórico marxista, mas interrogá-lo do ponto de vista de que a emancipação prevista a partir da evolução da ciência e da técnica não teria ocorrido. Demonstrando que a aparente contradição entre as forças produtivas e as relações de produção, na realidade, seria uma identidade, Adorno evidencia que mesmo a análise dialética marxista não está isenta da possibilidade de gerar falsas sínteses. Dessa forma, para Adorno, a tarefa da dialética não deveria ser a de esperar que contradições no mundo real se transformem em sínteses. Marx, por sua vez, teria, na verdade, através de sua tese sobre o caráter contraditório do capitalismo, que apontaria para sua extinção, encontrado uma alternativa para a crise do próprio capitalismo.

Adorno, então, procura libertar a dialética do que considera uma essência afirmativa. Para isso, propõe a dialética negativa, que seria a consciência consequente da não-identidade, uma vez que esta não recebe, de antemão, um ponto de vista idealizado. Emerge assim a categoria "constelação", que seria o esforço do conceito de superar a sua própria insuficiência inevitável, categoria esta que não apenas não admite definição como também é refratária a qualquer tratamento teórico que tente isolá-la de suas configurações concretas. A dialética como índice da insuficiência inevitável do pensamento se desprenderia assim do idealismo, tomando com ponto de partida a primazia do objeto. Traduzindo: querendo evitar a afirmação de antemão (a resolução das contradições - identidade), a dialética negativa coloca a negação de antemão (a manutenção das contradições - não-identidade); assim, a opressão já está dada, cristalizou-se na realidade, de modo que não há nem forma do sujeito superá-la e nem utopia a vista. O que permanece é uma dialética interminável, uma crítica imobilizada, pois cada juízo concluído requer nova negação e retenção do juízo. Essa elaboração adorniana, que o aproxima do ceticismo, de alguma forma, justifica porque ele costuma ser apontado como um dos precursores do pós-estruturalismo.

No entanto, há aqui um problema, identificado por Nobre (1998), que pode ser endereçado igualmente aos pósestruturalistas: a ilusão do pensamento e a própria verdade se entrelaçam, uma vez que o idealismo não é simplesmente inverdade, mas verdade em sua inverdade. O idealismo contém em si um potencial: a ideia mediada pela práxis pode se transformar em realidade Quando a crítica se torna imobilizada, ela se aprisiona no 
real e perde sua capacidade de transcendência: ela se torna cativa da caverna de Platão. Ora, como já foi dito, fora do idealismo não há crítica e nem possibilidade de mudança, e a dialética negativa, dessa forma, acaba conduzindo Adorno, assim como mais tarde aconteceria com os pós-estruturalistas, à paralisação da ação: a realidade se impõe de tal forma, que nada se pode fazer para mudá-la, de modo que a crítica se desvincula da práxis, imobilizando-se.

Nesse ponto, cabe indagar: o pós-estruturalismo pode ser crítico? Alcadipani e Tureta (neste número) procuram no artigo apresentado a este fórum demonstrar que sim. Em estudos anteriores (PAES DE PAULA, 2008), apontamos as dificuldades de se manter o caráter critico de uma filosofia que advoga a morte do sujeito, mas também argumentamos que seria possível reconstituir seu fundamento crítico resgatando esse mesmo sujeito e o conteúdo ético-político. No artigo que assinamos neste fórum, admitimos que o pós-estruturalismo vem sendo mal utilizado e que deveria ser levado mais a sério, pois algumas revisões poderiam levar a um novo movimento teórico reconciliado com a crítica. Por outro lado, depois de tudo que argumentamos neste texto, é impossível não considerar que o pós-estruturalismo também seja crítico: suas simetrias com os dilemas adornianos são um prova disso, além do que também comprovam as dificuldades da crítica que se recusa a recorrer ao idealismo diante de uma realidade que não aponte saídas para a transformação. $\mathrm{O}$ jogo da diferença é uma forma de pensar, de filosofar que busca a verdade tal como a dialética marxista, a dialética negativa e, como veremos, mais adiante, a fenomenologia: todas elas são, a seu modo, uma maneira de criticar.

Com essas reflexões, também pretendíamos comprovar que não é possível afirmar que as bases epistemológicas e teóricas da teoria crítica sejam a centralidade da categoria trabalho, a análise materialista histórica e o materialismo dialético. Todos esses elementos são, na realidade, profundamente interrogados pelos frankfurtianos, que embora não descartem o marxismo, estão longe de abraçá-lo na perspectiva economicista, pois defendem uma dialética entre materialismo e idealismo. Por outro lado, não é possível afirmar que a teoria crítica se fundamente na primazia do real, pois ainda que a questão do materialismo esteja presente, principalmente, nas elaborações de Adorno - que, inclusive, considera Marx um idealista tardio -, o idealismo se coloca como imprescindível para a existência da crítica ativa e da própria filosofia. Não há primazia do real ou do ideal, mas, sim, uma dialética.

Quais seriam as bases epistemológicas e teóricas da teoria crítica? Um pensamento marxista que interroga sua face materialista por meio do resgate de sua perspectiva filosófica, a psicanálise freudiana (que não vamos tratar aqui por definitiva falta de espaço e oportunidade), o idealismo alemão, a categoria cultura, o ideal emancipatório e a perspectiva humanista. Essas influências evidenciam o caráter profundamente heterodoxo da teoria crítica e demonstram que ela não teria existido sem o idealismo alemão, que a antecedeu e que também foi um movimento filosófico crítico. Kant, um de seus principais representantes, é conhecido por suas três críticas (da razão pura, da razão prática e do juízo), além de ter caracterizado a crítica do mesmo modo que fariam os frankfurtianos: saída do homem de seu estado de menoridade; ou seja, superação da incapacidade de se servir de seu entendimento sem a direção de outrem, o que significa o alcance da emancipação.

Essa mesma caracterização, provavelmente, teria sido feita por Platão, como pudemos averiguar no seu famoso mito da caverna. Antes de Kant, La Boétie (1982), no século XVI, escreveu o libertário Discurso da servidão voluntária, que talvez possa ser considerado um dos primeiros tratados de teor crítico da era moderna. Em uma entrevista concedida no século XX, Foucault (1990), fazendo eco a La Boétie, definiu a crítica como a "arte da servidão voluntária, da indocilidade refletida". Pode parecer supérfluo, mas ainda assim é importante dizer: a crítica existia antes de Marx e continua existindo, apesar de alguns tipos de marxismos.

\section{0 testemunho da fenomenologia e do existencialismo: sobre como Guerreiro Ramos foi absolvido}

E o que dizer das tradições filosóficas que foram contemporâneas à teoria crítica, como a fenomenologia e o existencialismo? Será que podem ser consideradas críticas? Apesar de ser uma temeridade querer caracterizálas em poucas páginas e com algumas afirmações, acreditamos que vale a pena um esforço para demonstrar que são críticas, até mesmo porque são correntes filosóficas. Obviamente, não se tratam de teoria crítica, até porque, em algum momento, rivalizaram com ela, o que, no entanto, não as impediu de serem críticas. 
Vamos começar pela fenomenologia. Curiosamente, ela constituiu a base de formação de Adorno, tendo sido o tema de sua tese de doutorado "A transcendência do objeto e do noemático na fenomenologia de Husserl". Sua conclusão? A fenomenologia não teria conseguido se libertar dos pressupostos do idealismo. Ao que agora temos condições de retrucar: os frankfurtianos, incluindo o próprio Adorno, conseguiram? De qualquer forma, é importante olhar mais de perto os conceitos que amparam o pensamento fenomenológico, como por exemplo, a discutida atitude (ou redução fenomenológica).

Em um esclarecedor livro sobre a fenomenologia, Sokolowski (2004) afirma que a atitude fenomenológica consiste em se desprender da atitude natural e alcançar um modo reflexivo; nas suas próprias palavras, "tornarser um filósofo". A base da fenomenologia é ideia de que cada ato humano é intencional, no sentido de que dirige a consciência a um objeto. Além disso, a fenomenologia coloca que a mente humana não é uma caixa fechada, mas uma coisa pública, pois tudo lhe é externo, de modo que os fenômenos são na verdade a consciência da existência do mundo real; em outras palavras, a consciência nasce do contato com a realidade. No entanto, essa realidade tem uma multiplicidade e também está sendo sempre analisada pela perspectiva de outra pessoa, que pode ter visto um aspecto dessa multiplicidade que o outro não percebeu. $\mathrm{O}$ objeto da fenomenologia é exatamente atingir a multiplicidade da realidade.

Quando nos encontramos em atitude natural, a nossa tendência é dirigir nossas intenções à realidade, apreendendo-a de acordo com os aspectos que percebemos de sua multiplicidade. Como seria de se esperar, algo sempre nos escapa. Em contraposição, a atitude (ou redução fenomenológica) nos permitiria "suspender temporariamente" nossas intenções para analisar a multiplicidade da realidade e, também, as nossas próprias intenções. Nas palavras de Sokolowski (2004, p.58-59):

Esta suspensão, esta neutralização de nossas modalidades dóxicas é também chamada de epoché, um termo tomado do ceticismo grego, que significa a retenção que o cético dizia que deveríamos ter com respeito a nossos juízos sobre as coisas; eles diziam que deveríamos reter o juízo até que a evidência fosse clara. [...] Quando entramos em atitude fenomenológica, suspendemos nossas crenças e pomos entre colchetes o mundo e todas as coisas do mundo. [...] quando entramos na atitude fenomenológica, nós rastejamos para fora da atitude natural, elevamos-nos sobre ela, nós a teorizamos, distinguimos e descrevemos a ambos os correlatos subjetivos e objetivos que a compõem. A partir de nosso poleiro filosófico, descrevemos as várias intencionalidades e seus vários objetos, assim como o si mesmo e o mundo.

Em outras palavras, a fenomenologia nos pede: pare de julgar e veja as coisas como elas são, inclusive, você mesmo, e julgue novamente quando tudo estiver mais claro. É impossível não fazer um paralelo com a crítica, que, como vimos, tem como bases a verdade e a dúvida. Os próprios céticos, que não por acaso foram citados anteriormente, colocam a necessidade de "olhar à distância" e "observar", para, então, julgar e concluir se o conhecimento e a percepção são verdadeiros. A fenomenologia se coloca então como uma forma de crítica, que, certamente, não é a mesma realizada pela dialética marxista e por outras dialéticas, mas que igualmente interroga a verdade. Ora, mas o próprio Adorno não colocou que era preciso libertar a dialética marxista de sua essência afirmativa, impedindo que esta colocasse de antemão um ponto de vista idealizado? Qual seria então a diferença da fenomenologia e da dialética liberta de seu caráter afirmativo, visto que ambas, na busca da verdade, tentam suspender o julgamento? Ao que parece, a dialética negativa evita a afirmação a priori (a resolução das contradições - identidade), mas estabelece a negação a priori (a manutenção das contradições não-identidade), gerando uma retenção contínua do juízo, pois todo julgamento concluído é negado e novamente colocado em suspenso. Já a fenomenologia não estabelece nem negação e nem afirmação a priori, permitindo ao sujeito escolher se quer continuar julgando, uma vez que, embora empreste a epoché dos gregos, a implicação cética não é preservada, pois aqui quer dizer neutralização das intenções naturais para que elas sejam contempladas; ou seja, a retenção do juízo é temporária.

O interessante é que a fenomenologia, da mesma forma que a dialética negativa, evidencia a importância do mundo material, pois de acordo com Sokolowski (2004, p.71-72); 
A fenomenologia é parasita da atitude natural e de todas efetividades dela. A fenomenologia não tem acesso às coisas e manifestações do mundo, exceto através da atitude natural e suas intencionalidades. A fenomenologia chega somente mais tarde. Tem de ser modesta; ela deve reconhecer a verdade e a validade das efetividades da atitude natural, nos seus exercícios prático e teórico. Então, contempla essas efetividades e suas atividades subjetivas correlatas, mas se as efetividades não estivessem lá, nada haveria para a filosofia pensar. [...] Quando a fenomenologia "neutraliza" as intencionalidades que operam na atitude natural, não as dilui, destrói, recalca ou ridiculariza. Ela meramente adota uma estância contemplativa em direção a elas, uma instância da qual pode teorizá-las. A fenomenologia complementa a atitude natural; a filosofia complementa a opinião verdadeira e a ciência.

A fenomenologia não desconsidera a primazia do real, apenas se distancia dele para teorizá-lo. O seu projeto é resgatar a filosofia do positivismo no qual ela estava se afundando, e para isso a fenomenologia busca um posicionamento crítico: reconhece a importância do mundo material, mas não descarta o mundo das ideias. É uma forma de pensar que não seria rechaçada por Horkheimer (1980b, p.161), para quem "A filosofia que pretende se acomodar em si mesma, repousando numa verdade qualquer, nada tem a ver com a teoria critica." É também uma forma de pensar que tem suas simetrias com o filosofar adorniano, embora, seja criticada por Adorno por seu idealismo, uma vez que poderia continuar negando os juízos e a verdade, embora possibilite ao sujeito escolher uma verdade na qual queira apostar. Como a escolha é do sujeito, a fenomenologia não estabelece a priori quais seriam as saídas políticas, o que a torna objeto de crítica dos marxistas politicamente engajados: não tem nada a dizer sobre a dimensão política da modernidade, embora tenha muito a dizer sobre a epistemologia e a metodologia. É uma das bases da psicologia e tem muitas contribuições a dar à psicanálise: precisa ser, com certeza, mais explorada.

Passamos agora ao existencialismo. Em primeiro lugar, é importante considerar que ele está profundamente enraizado na própria fenomenologia, podendo ser considerado, inclusive, uma radicalização da fenomenologia. Quando os existencialistas colocam que a existência precede a essência, não estão afirmando que o ser do homem é uma "tabula rasa", um "papel em branco" ou um "receptáculo vazio". Muito pelo contrário, estão dizendo que existir é uma condição ontológica que antecede o ser no mundo: o sujeito, em primeiro lugar, se percebe e, depois, percebe o mundo, adquirindo as essências que o definem. Se quando vem ao mundo o homem é vazio ou já traz algo a priori, é uma questão metafísica, até mesmo teológica, ${ }^{4}$ que não pretendemos esgotar: não por acaso, os existencialistas se dividiam entre ateus e cristãos.

Os existencialistas fazem a distinção entre a existência, que é ontológica, e a essência, que é socialmente construída, para comprovar que o homem é fruto de suas escolhas e livre para fazê-las, ainda que não costume ver-se como portador dessa liberdade, abdicando muitas vezes de sua condição de sujeito e se conformando com as diversas formas de opressão. Em outras palavras, os existencialistas politizam a fenomenologia, pois retomam, por meio da questão da liberdade humana, a possibilidade de escolha do sujeito. No entanto, não a analisam de uma forma neutra: estabelecem que o sujeito pode "escolher" entre ser livre ou prisioneiro, apontando a liberdade como condição humana. O existencialismo, assim como as tradições filosóficas que lhes são irmãs (idealismo alemão, fenomenologia e teoria crítica) é radicalmente humanista, uma vez que herdou o antropocentrismo da filosofia grega e do pensamento renascentista.

Tanto a fenomenologia quanto o existencialismo fazem crítica à sua maneira. Quanto à Sartre, não vamos cometer mais injustiças: já bastam todas as outras que lhe aconteceram. Só queremos alertar ao leitor que, se quiser, de fato, conhecer o pensamento de Sartre, primeiro de tudo, leia Sartre, faça suas próprias críticas e somente depois leia os seus críticos. Aliás, isso vale para qualquer autor que se queria conhecer bem. Sartre, bem como suas relações com o marxismo, não é algo que possa ser decifrado em algumas linhas sem que se cometam distorções. Talvez, no futuro, venhamos a nos debruçar sistematicamente sobre o seu pensamento, mas, no momento, isso é tudo o que podemos dizer.

\footnotetext{
${ }^{4}$ Aqui, a metafísica está sendo tratada como um sistema filosófico voltado para compreensão ontológica, teológica ou suprassensível da realidade (Dicionário Houaiss).
} 
Em síntese, o que podemos concluir é que a teoria critica, a fenomenologia e o existencialismo são tributários do idealismo alemão - sem o qual não poderiam existir - e também do humanismo. O marxismo, por sua vez, quando radicalmente materialista e fundamentalmente estruturalista, tem seu caráter crítico enfraquecido. Quando se alinha com as tradições filosóficas idealistas, no entanto, tende a fortalecê-lo. Queiram ou não os marxistas, Marx também foi profundamente influenciado pelo idealismo alemão e pelo humanismo. A questão que fica é porque correntes que têm tantas influências em comum e que partilharam alguns momentos históricos se colocam como se estivessem em campos distintos? Voltamos então ao que foi colocado no início deste texto: disputa de espaço acadêmico, divergências ideológicas, diferenças epistemológicas, interesses políticos?

Talvez nada disso explique, mas o fato é que o próprio Foucault $(1983$, p.29) uma vez reconheceu em uma entrevista "se eu tivesse me familiarizado com a Escola de Frankfurt [...] não teria dito várias das coisas estúpidas que disse e teria evitado muitos desvios ao tentar seguir meu próprio caminho - enquanto, nesse meio tempo, avenidas eram abertas pela Escola de Frankfurt”.

O que teria, então, impedido essa familiarização? Por que motivo os frankfurtianos dirigiram críticas à fenomenologia e ao existencialismo? Algo semelhante estaria acontecendo no campo dos estudos organizacionais críticos no Brasil quando seus representantes insistem em demarcar o que é a verdadeira crítica? Isso nos leva ao caso de Guerreiro Ramos.

Em primeiro lugar, cabe esclarecer que nós (PAES DE PAULA, 2004, 2007, 2008) não afirmamos que Guerreiro Ramos estivesse vinculado à teoria crítica ou que fosse a ela filiado: o que apontamos em nossos textos é que Guerreiro Ramos realizou estudos organizacionais críticos e que pode ser caracterizado como um fenomenólogo crítico. Em segundo lugar, não associamos Guerreiro à teoria crítica, mas apenas demarcamos que A nova ciência das organizações foi influenciada, de algum modo, pelo pensamento frankfurtiano, pois a crítica que Guerreiro faz da racionalidade instrumental é fundamentalmente apoiada na Escola de Frankfurt. Ao considerarmos a centralidade da questão das racionalidades para sua enunciação da nova ciência das organizações, não podemos dizer que essa influência seja de pouca importância. Além disso, quando discutimos o existencialismo de Guerreiro Ramos (PAES DE PAULA, 2008), citamos Sartre, sintetizando as principais categorias dessa corrente filosófica, mas não dissemos que Guerreiro Ramos se vinculava a Sartre. O estudo aprofundado de sua biografia demonstrou claramente uma afinidade, desde a juventude, com o existencialismo cristão de Berdiaeff. Além do mais, sabemos que, como isebiano, Guerreiro Ramos foi profundamente influenciado por leituras existencialistas, nas quais, provavelmente, inclui-se a obra de Sartre. O fato de Sartre não ter sido sequer mencionado em A nova ciência das organizações não significa que Guerreiro Ramos não o tenha lido, nem que não tenha sofrido influências de leituras existencialistas.

Ainda que Guerreiro Ramos não seja um marxista, e já discutimos anteriormente as razões disto (PAES DE PAULA, 2008), sua forma de analisar a economia de mercado não pode ser objeto de simplificações. Não é meramente casual que o subtítulo do livro seja Uma reconceituação da riqueza das nações, o que demonstra claramente sua crítica a Adam Smith e sua opção totalmente consciente de não recorrer a Karl Marx para fazêla. Por outro lado, ainda que essa opção tenha dado margem à acusação de que sua análise da economia de mercado apresentava fragilidades, Guerreiro Ramos manteve uma posição que nos parece fundamental para sustentar sua crítica. Ele afirmou corajosamente que não há emancipação possível para os homens nas organizações econômicas, antecipando-se não só em diagnosticar o equívoco dos métodos de integração e de melhoria da qualidade de vida promovidos pela administração, como também o absurdo do gerencialismo engajado promovido por alguns representantes do movimento critical management studies.

Humanista radical, sim, na medida em que para Guerreiro Ramos o centro da mudança é o homem. Ainda que ele tenha utilizado a categoria "homem parentético", isso não reduz o vigor da sua elaboração, já que categorias também foram utilizadas pelo próprio Adorno em seus estudos sobre a "personalidade autoritária". Teórico crítico, não, pois essa nomenclatura, ao nosso ver, é exclusiva da Escola de Frankfurt. Ainda que Nobre (2004) tenha apontado o marxismo como teoria crítica lato sensu, questionamos a validade dessa assertiva, pois apesar dos pontos de contato, o marxismo e a teoria crítica são projetos intelectuais distintos. Crítico, sim, na medida em que fez uso da crítica fenomenológica, defendendo que é impossível o exercício da crítica sem o 
conhecimento filosófico. Não é um marxista e nem nunca utilizou o método dialético, mas, por sua confiança na condição humana de liberdade e na possibilidade da transformação social, o apontamos como um estudioso crítico, uma vez que prestou inegáveis serviços ao desenvolvimento dos estudos organizacionais críticos no Brasil.

Cabe ainda uma colocação final. Entre os pensadores brasileiros, há outro isebiano radicalmente humanista, afeito à fenomenologia e ao existencialismo cristão, que numa segunda etapa de seu desenvolvimento intelectual, na década de 1970, foi influenciado por um marxismo não economicista, por Gramsci e por Sartre (SCOCUGLIA, 1999). Um dos seus primeiros livros, datado de 1967, é um belo tratado sobre a educação e a liberdade: um trabalho seminal, tributário do pensamento de Guerreiro Ramos, especialmente, da redução sociológica e de sua categoria "homem parentético".

De tanto insistirem essas sociedades nas soluções transplantadas, sem a devida redução - ver Guerreiro Ramos - A Redução Sociológica - que adequaria às condições do meio, terminam as suas gerações por se entregarem ao desânimo e a atitudes de inferioridade.

Em recente ensaio, opõe Guerreiro Ramos ao "rinocerontismo", o que ele chama de "homem parentético". O homem que põe sempre entre "parênteses" antes de definir-se para optar. O homem parentético não é um cético nem um tímido. É crítico. Há uma certa relação entre o homem parentético de Guerreiro Ramos e a "imaginação sociológica" de Wright Mills.

Será que ele também não é critico?

Seu nome? Paulo Freire (2006, p.53 e 61). 


\section{Referências}

ADORNO, T. W. Marx superado? In: et al. Marx superado? Buenos Aires: Distribuidora Baires, 1974. Dialéctica negativa. Madrid: Taurus, 1975.

; HORKHEIMER, M. Dialética do esclarecimento: fragmentos filosóficos. Rio de Janeiro: Zahar, 1985.

FOUCAULT, M. Structuralism and post-structuralism: an interview with Michel Foucault. Telos, n.55, p.195-211, 1983.

Qu'est-ce que la critique? Critique et Aufklärung. Bulletin de la Societé Française de Philosophie, v. 82, n.2, p.35-63, avril/juin, 1990.

FREIRE, P. Educação como prática da liberdade. 29.ed. Rio de Janeiro: Paz e Terra, 2006.

HABERMAS, J. 0 discurso filosófico da modernidade. Lisboa: Dom Quixote, 1990.

HORKHEIMER, M. Teoria tradicional e teoria crítica. In: BENJAMIN, W. et al. Textos escolhidos. São Paulo: Abril Cultural, 1980a. (Coleção Os Pensadores).

. Filosofia e teoria crítica. In: BENJAMIN, W. et al. Textos escolhidos. São Paulo: Abril Cultural, 1980b. (Coleção Os Pensadores).

LA BOÉTIE, E. 0 discurso da servidão voluntária ou o contra um. In: CLASTRES, P.; LEFORT, C.; CHAUÍ, M. S. Discurso da servidão voluntária. São Paulo: Brasiliense, 1982.

MARCUSE, H. Ideologia da sociedade industrial. Rio de Janeiro: Zahar, 1979.

NOBRE, M. A dialética negativa de Theodor W. Adorno. A ontologia do Estado falso. São Paulo: lluminuras/Fapesp, 1998.

Teoria crítica. Rio de Janeiro: Zahar, 2004.

PAES DE PAULA, A. P. Repensando os estudos críticos em administração. Revista de Administração de Empresas, São Paulo, v.44, n.2, p.114-115, 2004.

Guerreiro Ramos: resgatando o pensamento de um sociólogo crítico das organizações. Organizações \&t Sociedade, v.14, p.169188, 2007.

Teoria crítica nas organizações. São Paulo: Thomson: 2008.

SCOCUGLIA, C. Origens e prospectiva do pensamento político-pedagógico de Paulo Freire. Educação e Pesquisa, São Paulo, v.25, n.2, p.25-37, jul./dez. 1999.

SOKOLOWSKI, R. Introdução à fenomenologia. São Paulo: Loyola, 2004. 